\title{
The Effect of Neutrophil-to-Lymphocyte Ratio, Platelet-to-Lymphocyte Ratio, and Mean Platelet Volume in Surgical Decision and Follow-up of Adenotonsillectomy
}

\author{
(1) Hacer Baran, (1) Melis Demirağ Evman, (1) Hakan Avcl
}

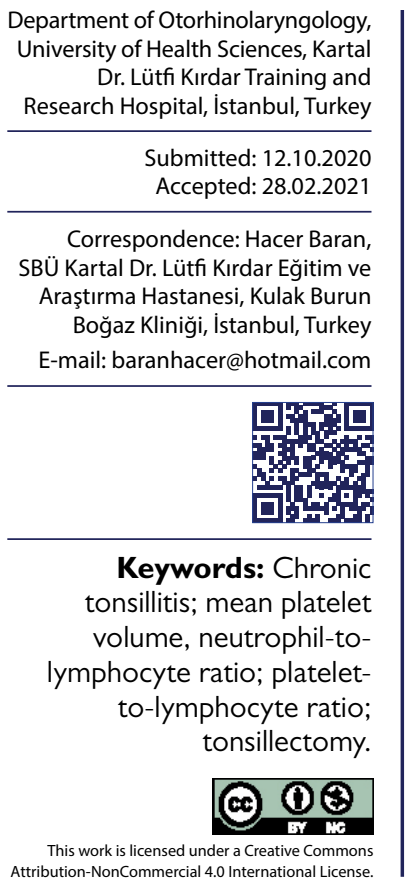

\begin{abstract}
Objective: Adenotonsillectomy/tonsillectomy are among the most widely used surgical procedures in ENT. The aim of the study is to compare the pre- and post-operative values of neutrophil/lymphocyte ratio (NLR), platelet/lymphocyte ratio (PLR), and mean platelet volume (MPV) according to the number of recurrent infections and to determine its relation to the normal population.
\end{abstract}

Methods: Complete blood cell values of 194 patients who underwent surgery for chronic tonsillitis and tonsillar hypertrophy as a study group, 83 patients with normal values as control group were analyzed for NLR, PLR, and mean platelet volume. Annual number of infections and blood parameters were compared before and after surgery.

Results: Pre-operative NLR values of 194 patients in the study group were significantly higher than the post-operative values. In terms of MPV, pre-operative, post-operative, and control groups were statistically different from each other in 3 groups. When the parameters were examined in terms of number of infections, no significant difference was observed between groups in terms of NLR, PLR, and MPV values.

Conclusion: We did not found any relationship between the annual number of infections and inflammatory blood parameters. Therefore, in terms of the number of infections per year, these parameters are not significantly valuable. However, in patients who underwent surgical procedures, NLR was significantly higher in the normal population and postoperatively than in the pre-operative period. Therefore, we believe the NLR may be used as an inflammatory marker in tonsillitis patients.

\section{INTRODUCTION}

Tonsillectomy and adenotonsillectomy are among the most common surgical procedures in otorhinolaryngology practice. Initially, the most common indication for these surgical interventions was chronic or recurrent infections, but with the frequent use of antibiotics, airway obstruction, and sleep apnea indications have increased. ${ }^{[l]}$ Recently, there is an increase in studies aiming to predict the prognosis of patients with simple blood tests related to the relationship between the inflammatory status and the prognosis of the disease or cancer. For this purpose, complete blood count (CBC) parameters such as neutrophil-to-lymphocyte ratio (NLR), platelet-to-lymphocyte ratio (PLR), and mean platelet volume (MPV) are frequently used. ${ }^{[2]}$ The increase in neutrophil count reflects ongoing inflammation, while low lymphocyte count reflects malnutrition and inflammatory status. Several studies have shown that NLR is an import- ant marker in the assessment of the inflammation process. [3,4] Platelets are a rich source of inflammatory cytokines and play an active role in inflammation while having regulatory effects on immune cells. Similarly, PLR is also used as a marker for the inflammation process. ${ }^{[5]}$ Besides, MPV, which reflects platelet production rate and stimulation and is indicated in routine blood cell analysis, has been shown to correlate with various inflammatory diseases such as neonatal sepsis and acute pyelonephritis. ${ }^{[6,7]}$ In our study, it was aimed to investigate the relationship between annual recurrent infection numbers and NLR, PLR, and MPV in patients who underwent tonsillectomy and adenotonsillectomy.

\section{MATERIALS AND METHODS}

This retrospective study was approved by the clinical trials and ethics committee of our hospital. In this study, 194 patients who underwent tonsillectomy and adenotonsil- 
lectomy at our otolaryngology clinic due to chronic or recurrent infection or upper airway obstruction and sleep apnea between January and December 2018 and 83 healthy controls who were admitted to our hospital for various reasons and who did not receive antibiotherapy for the last I year were included in the study. CBC values were evaluated I day before and I month after surgery. $\mathrm{CBC}$ values of 83 patients in the control group were obtained from the patient records. Patients who were not followed up postoperatively or whose control $C B C$ values were not measured in the Ist month were excluded from the study. Patients with a diagnosis of chronic inflammation such as chronic lung or kidney disease, craniofacial anomaly, allergic rhinitis, hypothyroidism, and malnutrition were excluded from the study.

After retrospective file analysis, the patients were divided into four groups according to the number of infections per year. Any sore throat with at least one of the criteria of the fever higher than $38.5^{\circ} \mathrm{C}$, cervical adenopathy, tonsil exudate, or positive group A beta-hemolytic streptococcus test was considered an infection attack. Patients according to the annual number of recurrent infections were classified as Group I with infection history 0-3 times, Group 2 with history of infection 4-7 times, Group 3 with infection 8-10 times, and Group 4 with infection 10 and above. Tonsillar grade and adenoid grade were noted from patient records. Tonsil size was graded according to Brodsky Grading scale, and adenoid tissue was graded according to Cohen and Konak method. ${ }^{[8,9]}$ The patients' apnea history was asked to their parents. The control group consisted of 83 healthy children who underwent anemia treatment at the Department of Pediatrics and had normal CBC counts at 6 months follow-up. These patients did not receive any surgical treatment. Complete blood cell count and automatic differential count were determined by using a Sysmex XT 2000i fluorescence flow cytometer (Sysmex, Kobe, Japan) providing total white blood cell (WBC), neutrophil, and lymphocyte counts per microliter. The proportions were calculated as; NLR; the number of neutrophils per microliter, divided by the number of lymphocytes per microliter and PLR; the number of platelets per microliter, divided by the number of lymphocytes per microliter. MPV values were calculated automatically by devices in routine $C B C$ parameters.

\section{Statistical method}

The suitability of the data for normal distribution was analyzed by the Shapiro-Wilk test. Student's t-test was used for the data showing normal distribution among the variables in two independent groups of the data. Furthermore, Mann-Whitney $U$ test was used for the rest. The relationship between two independent variables at the categorical measurement level was tested by Chi-square. Pre- and post-operative comparisons were made with the Wilcoxon test. For descriptive statistics, mean \pm standard deviation for numerical variables and number and \% for categorical variables. SPSS Windows program was used for statistical analysis and $\mathrm{p}<0.05$ was considered statistically significant.

\section{RESULTS}

A total of 194 patients (I I 7 boys, 77 girls) who underwent adenotonsillectomy and tonsillectomy were included in the study. Control group consisted of 83 patients; 4 I boys and 42 girls. The mean age of the patients in the study group was 7.I, while the mean age of the patients in the control group was 4.7. While 106 (54.6\%) of the patients in the study group had witnessed apnea, 88 (45.4\%) had no apnea. When retrospective histories of patients were evaluated according to the number of infections per year, $38(19.6 \%)$ of the patients had 0-3 times, 74 (38.1\%) had 4-7 times, 32 (16.5\%) had 8-10 times, and 50 (25.8\%) had more than 10 infections per year. Ear, nose, and throat examinations of patients were classified according to their right and left tonsil grades and adenoid grade. Right tonsil grade I was $14.9 \%$ (29), grade 2 was $41.2 \%$ (80), grade 3 was $35.6 \%(69)$, and grade 4 was $8.2 \%(16)$. Left tonsil grade I was $18.6 \%$ (36), grade 2 was $39.7 \%$ (77), grade 3 was $33.5 \%(65)$, and grade 4 was $8.2 \%$ (16). When the patients were classified according to the presence of adenoid tissue by endoscopic examination, grade I was seen in $19.6 \%$ (38), grade $228.4 \%$ (55), grade $325.8 \%$, and grade $426.3 \%$ (5I). Adenotonsillectomy was performed to 160 patients and tonsillectomy was performed to 34 patients. When the CBC parameters of the patients were examined, the mean NLR was $1.21 \pm 0.79$, the mean PLR was $103.1 \pm 37.15$, and MPV was $9.03 \pm 5.78$ in the pre-operative period, and the mean NLR was I.58 \pm 1.07 , PLR was

Table I. Comparison of the patients in the study group before and after the operation

\begin{tabular}{lccc}
\hline Complete blood count parameters & Pre-operative & Post-operative & p-value \\
\hline White blood cell & $12.14 \pm 14.94$ & $7.68 \pm 3.68$ & 0.001 \\
Neutrophil & $9.36 \pm 46.67$ & $3.64 \pm 2.86$ & 0.001 \\
Lymphocyte & $5.5 \pm 15.01$ & $3.27 \pm 1.45$ & 0.062 \\
Platelet & $323.95 \pm 84.8$ & $305.61 \pm 77.87$ & 0.001 \\
Neutrophil-to-lymphocyte ratio & $1.58 \pm 1.07$ & $1.21 \pm 0.79$ & 0.001 \\
Platelet-to-lymphocyte ratio & $103.8 \pm 47.31$ & $103.04 \pm 37.15$ & 0.370 \\
Mean platelet volume & $12.97 \pm 18.21$ & $9.03 \pm 5.78$ & 0.579 \\
\hline
\end{tabular}


$323.95 \pm 84.8$, and MPV was $12.97 \pm 18.21$ in the post-operative period. In the control group, the mean NLR was $1.25 \pm 1.55$, PLR 109.78 \pm 111.97 , and the mean MPV was $8.27 \pm 0.72$. When the pre-operative and post-operative values of the patients in the study group were compared, a statistically significant difference was found between the two groups in terms of WBC, platelet, neutrophil count, and NLR, but no statistically significant difference was found in lymphocyte count and PLR (Table I).
When the pre-operative values were compared with the control group, statistically significant differences were observed in terms of NLR $(p=0.001)$. In the pre-operative group, the NLR (I.58 \pm 1.07$)$ was higher than the control (I.25 \pm 1.55$)$. Similar relationships were observed in neutrophil and MPV parameters between pre-operative and control groups $(p<0.05)$ (Table 2$)$.

When the post-operative values were compared with the control group, statistically significant differences were

Table 2. Comparison of the pre-operative values of the study group with the control group

\begin{tabular}{lccc}
\hline Complete blood count parameters & Pre-operative & Control & p-value \\
\hline White blood cell & $12.14 \pm 14.94$ & $8.67 \pm 2.49$ & 0.259 \\
Neutrophil & $9.36 \pm 46.67$ & $3.62 \pm 1.33$ & 0.001 \\
Lymphocyte & $5.5 \pm 15.01$ & $3.63 \pm 1.29$ & 0.103 \\
Platelet count & $323.95 \pm 84.8$ & $320.63 \pm 71.25$ & 0.959 \\
Neutrophil-to-lymphocyte ratio & $1.58 \pm 1.07$ & $1.25 \pm 1.55$ & 0.001 \\
Platelet-to-lymphocyte ratio & $103.8 \pm 47.31$ & $109.78 \pm 111.97$ & 0.084 \\
Meanplatelet volume & $12.97 \pm 18.21$ & $8.27 \pm 0.72$ & 0.012 \\
\hline
\end{tabular}

Table 3. Comparison of the post-operative values of the study group with the control group

\begin{tabular}{lccc}
\hline Complete blood count parameters & Post-operative & Control & p-value \\
\hline White blood cell & $7.68 \pm 3.68$ & $8.67 \pm 2.49$ & 0.001 \\
Neutrophil & $3.64 \pm 2.86$ & $3.62 \pm 1.33$ & 0.073 \\
Lymphocyte & $3.27 \pm 1.45$ & $3.63 \pm 1.29$ & 0.002 \\
Platelet count & $305.61 \pm 77.87$ & $320.63 \pm 71.25$ & 0.054 \\
Neutrophil-to-lymphocyte ratio & $1.21 \pm 0.79$ & $1.25 \pm 1.55$ & 0.291 \\
Platelet-to-lymphocyte ratio & $103.04 \pm 37.15$ & $109.78 \pm 111.97$ & 0.077 \\
Mean platelet volume & $9.03 \pm 5.78$ & $8.27 \pm 0.72$ & 0.005 \\
\hline
\end{tabular}

Table 4. Comparison of pre-operative and post-operative values by the number of infections per year

\begin{tabular}{|c|c|c|c|c|c|c|c|c|c|c|}
\hline \multirow[t]{3}{*}{ Ratio } & \multicolumn{8}{|c|}{ Number of infections per year } & \multirow[t]{3}{*}{$\mathbf{F}$} & \multirow[t]{3}{*}{$\mathbf{p}$} \\
\hline & \multicolumn{2}{|c|}{$0-3$} & \multicolumn{2}{|c|}{ 4-7 } & \multicolumn{2}{|c|}{$8-10$} & \multicolumn{2}{|c|}{$>10$} & & \\
\hline & Mean & SD & Mean & SD & Mean & SD & Mean & SD & & \\
\hline Pre-operative platelet-to-lymphocyte ratio & 100.25 & 42.44 & 101.20 & 49.20 & 102.16 & 53.79 & 111.39 & 44.03 & 0.254 & 0.859 \\
\hline Post-operative platelet-to-lymphocyte ratio & 103.35 & 42.04 & 101.20 & 34.17 & 97.45 & 29.46 & 109.10 & 41.84 & 0.743 & 0.528 \\
\hline Pre-operative neutrophil-to-lymphocyte ratio & 1.50 & 1.17 & 1.53 & 0.88 & 1.57 & 1.13 & 1.72 & 1.22 & 0.484 & 0.693 \\
\hline Post-operative neutrophil-to-lymphocyte ratio & I.II & 0.72 & 1.16 & 0.53 & 1.38 & 1.22 & 1.23 & 0.81 & 0.805 & 0.492 \\
\hline Pre-operative neutrophil & 4.32 & 1.58 & 15.01 & 74.98 & 6.64 & 7.27 & 6.58 & 9.43 & 0.647 & 0.586 \\
\hline Post-operative neutrophil & 3.24 & 1.30 & 3.37 & 1.27 & 4.43 & 5.41 & 3.83 & 3.05 & 1.360 & 0.257 \\
\hline Pre-operative lymphocyte & 4.17 & 5.56 & 7.15 & 23.17 & 5.56 & 7.80 & 4.03 & 4.24 & 0.632 & 0.596 \\
\hline Post-operative lymphocyte & 3.17 & 0.93 & 3.17 & 0.98 & 3.22 & 0.95 & 3.52 & 2.35 & 0.685 & 0.562 \\
\hline Pre-operative platelet & 306.63 & 75.84 & 324.15 & 91.71 & 319.66 & 77.34 & 339.56 & 84.68 & 0.774 & 0.510 \\
\hline Post-operative platelet & 302.08 & 82.66 & 297.78 & 76.61 & 297.56 & 69.09 & 325.02 & 80.21 & 1.434 & 0.234 \\
\hline Pre-operative white blood cell & 8.67 & 1.78 & 13.32 & 17.39 & 13.85 & 17.10 & 11.94 & 15.09 & 0.963 & 0.411 \\
\hline Post-operative white blood cell & 7.28 & 1.86 & 7.38 & 1.91 & 7.49 & 1.79 & 8.55 & 6.50 & 1.27 & 0.284 \\
\hline Pre-operative mean platelet volume & 10.48 & 10.95 & 14.13 & 20.88 & 16.03 & 23.11 & 11.18 & 14.54 & 0.938 & 0.423 \\
\hline Post-operative mean platelet volume & 8.73 & 0.96 & 8.76 & 1.03 & 8.72 & 1.08 & 9.84 & 11.30 & 0.442 & 0.723 \\
\hline
\end{tabular}


observed in terms of WBC, lymphocyte count, and MPV values $(p<0.05)$. Lymphocyte values of the control group $(3.63 \pm 1.29)$ were higher than those of the control group $(3.27 \pm 1.45)$. A similar relationship was observed in WBC parameters in the post-operative and control groups. The difference in MPV values was found to be significantly different in post-operative and control groups, a statistically significant where MPV values were higher in the post-operative group (Table 3 ). When the patients were grouped according to the number of recurrent infections, WBC, neutrophil, lymphocyte, platelet counts, PLR, and NLR, there was no statistically significant difference between the groups in terms of pre-operative and post-operative values (Table 4).

\section{DISCUSSION}

Adenotonsillectomy and tonsillectomy are among the most common surgical procedures in pediatric patients. They have been applied more frequently for recurrent infections in previous years. Because of the widespread use of antibiotherapy, sleep disorder complaints seem to be a more common indication. ${ }^{[1]}$ In our clinic, adenotonsillectomy and tonsillectomy procedures are performed if there are 7 or more infections in the last I year, 5 or more in the last 2 years, or 3 in the last 3 years or if there is upper respiratory tract obstruction due to adenotonsillar hypertrophy. There are several studies made on adenotonsillar hypertrophy and chronic tonsillitis which may cause inflammation and follow-up of this may be important for the decision of surgery or follow-up. . $^{[3,10,11]}$

Studies on blood count parameters have shown that it is important in inflammation pathophysiology, hemostasis, oncogenesis, and immune response. ${ }^{[12-14]}$ Frequent use of these parameters can be explained as them being cheap and easily done in any laboratory. ${ }^{[14]}$ Among these, NLR, PLR, and MPV are the most commonly used ones. $[3,10,1,1,14,15]$ Neutrophils reflect the inflammatory response and lymphocyte count may be associated with stress and nutritional status. ${ }^{[16,1]]}$ Platelets, on the other hand, release various mediators besides its blood clotting mechanism, thus enabling the immune response to proceed. ${ }^{[18]}$

In cases of inflammation, specific leukocyte subset cells emerge. It is characterized by a decrease in lymphocyte count and an increase in neutrophil count in systemic bacterial infections. In this case, neutrophil accumulation and stem cell stimulation in the region, causing inflammation occurs, and lymphopenia develops by marginalization and redistribution of lymphocytes in the lymphatic system. ${ }^{[19]}$ Yenigun ${ }^{[3]}$ found that pre-operative values of NLR were significantly higher in patients with chronic tonsillitis than post-operative values of those patients and the normal population. NLR as a sign of systemic inflammation in chronic tonsillitis patients may be an easy method to determine the timing of surgical intervention and post-operative follow-up. Senturk et al. ${ }^{[14]}$ reported that it was an easy and rapid method to follow the inflammatory process with NLR in peritonsillar abscess patients. Similarly, in our study, we found that pre-operative values of NLR were significantly higher compared to the post-operative period and the normal population. There was no significant difference between the post-operative period and the normal population, which suggests that similar to other studies.

Platelets also play an important role in the development of the inflammatory response by releasing their pro-inflammatory particles. They may cause arthritis in rheumatic diseases and may cause various inflammatory events that may be complicated by cardiovascular, metabolic, infectious, and lymphoproliferative incidences. There are various studies about PLR which give data that PLR may be used in the inflammatory process. ${ }^{[12]}$ Like NLR, PLR is also an effective marker that reflects the inflammatory response associated with an increase in pro-inflammatory mediator levels, which are also considered as prognostic markers or predictors of systemic diseases, leading to an increased inflammatory state. ${ }^{[20,21]}$ In our study, when we compared the PLR values between groups, no significant difference was found between the pre-operative and post-operative periods and the normal population. Similarly, another parameter used in the follow-up of inflammation is MPV, which is automatically measured in routine blood tests and shows platelet activity. Large platelets contain dense granules, are enzymatically and metabolically more active, and have greater prothrombotic potential. As the volume increases, the number of granules and the number of adhesion receptors tend to increase in parallel, hence the risk of complications due to increasing hypercoagulopathy. ${ }^{[15,21,22]}$ In a study by Onder et al.,. ${ }^{[15]}$ pre-operative and post-operative values of MPV did not show a significant difference in patients who were performed adenoidectomy for upper airway obstruction. Cengiz et al. ${ }^{[10]}$ investigated the relationship between chronic tonsillitis and adenoid hypertrophy and MPV values; a negative correlation was found between obstructive sleep disorder and MPV values in children. In our study, a statistically significant difference was found between pre-operative, post-operative, and control groups in terms of MPV values. Although the pre-operative values were significantly higher than the post-operative values, they were significantly higher than the control group. MPV values were decreased after surgery, and however, MPV values were found to be higher than the normal population.

The starting point of our study was whether there was a relationship between the number of infections and inflammation markers. In a study by Yenigun, patients operated for chronic tonsillitis did not have significantly different NLR values than patients who underwent adenotonsillectomy for obstructive pathology. ${ }^{[3]}$ In our study, we investigated the relationship between NLR, PLR, MPV, and the annual number of infections. However, no significant correlation was found between the annual number of infections and the parameters used as the inflammation marker. While NLR in the pre-operative period was significantly higher than in the post-operative period and the control 
group, we observed that frequent infections had no effect on NLR, PLR, and MPV. We believe that further studies with larger patient groups are needed on this subject for more accurate results.

Ethics Committee Approval

This study approved by the Kartal Dr. Lütfi Kırdar Training and Research Hospital Clinical Research Ethics Committee (Date: 27.02.2019, Decision No: 2019/5 I4/I48/I7).

Informed Consent

Retrospective study.

Peer-review

Internally peer-reviewed.

Authorship Contributions

Concept: H.B.; Design: H.B., M.D.E.; Supervision: M.D.E.; Fundings: H.A.; Materials: H.B.; Data: H.A.; Analysis: H.A.; Literature search: M.D.E.; Writing: H.A., M.D.E.; Critical revision: H.A., M.D.E.

Conflict of Interest

None declared.

\section{REFERENCES}

1. Alexiou VG, Salazar-Salvia MS, Jervis PN, Falagas ME. Modern technology-assisted vs conventional tonsillectomy: A meta-analysis of randomized controlled trials. Arch Otolaryngol Head Neck Surg 2011;137:558-70.

2. Lee JS, Kim NY, Na SH, Youn YH, Shin CS. Reference values of neutrophil-lymphocyte ratio, lymphocyte-monocyte ratio, platelet-lymphocyte ratio, and mean platelet volume in healthy adults in South Korea. Medicine 2018;97:e11138.

3. Yenigun A. The efficacy of tonsillectomy in chronic tonsillitis patients as demonstrated by the neutrophil-to-lymphocyte ratio. J Laryngol Otol 2015;129:386-91.

4. Asahina A, Kubo N, Umezawa Y, Honda H, Yanaba K, Nakagawa H. Neutrophil-lymphocyte ratio, platelet-lymphocyte ratio and mean platelet volume in Japanese patients with psoriasis and psoriatic arthritis: Response to therapy with biologics. J Dermatol 2017;44:1112-1.

5. Uslu AU, Kucuk A, Sahin A, Ugan Y, Yllmaz R, Gungor T, et al. Two new inflammatory markers associated with disease activity score-28 in patients with rheumatoid arthritis: Neutrophil-lymphocyte ratio and platelet-lymphocyte ratio. Int J Rheum Dis 2015;18:731-5.

6. Guida JD, Kunig AM, Leef KH, McKenzie SE, Paul DA. Platelet count and sepsis in very low birth weight neonates: is there an organ- ism-specific response? Pediatrics 2003;111:1411-5.

7. Tekin M, Konca C, Gulyuz A, Uckardes F, Turgut M. Is the mean platelet volume a predictive marker for the diagnosis of acute pyelonephritis in children? Clin Exp Nephrol 2015;19:688-93.

8. Cohen D, Konak S. The evaluation of radiographs of the nasopharynx. Clin Otolaryngol Allied Sci 1985;10:73-8.

9. Brodsky L. Modern assessment of tonsils and adenoids. Pediatr Clin North Am 1989;36:1551-69.

10. Cengiz C, Erhan Y, Murat T, Ercan A, Ibrahim S, Ihsan G, et al. Values of mean platelet volume in patients with chronic tonsillitis and adenoid hypertrophy. Pak J Med Sci 2013;29:569-72.

11. Sahin C, Varim C, Uyanik M. Use of neutrophils to lymphocytes ratio as an Inflammation marker in patients with chronic tonsillitis. Georgian Med News 2016;259:62-5.

12. Gasparyan AY, Ayvazyan L, Mukanova U, Yessirkepov M, Kitas GD. The platelet-to-lymphocyte ratio as an inflammatory marker in rheumatic diseases. Ann Lab Med 2019;39:345-57.

13. Fan Z, Hao L, Chuanyuan T, Jun Z, Xin H, Sen L, et al. Neutrophil and platelet to lymphocyte ratios in associating with blood glucose admission predict the functional outcomes of patients with primary brainstem hemorrhage. World Neurosurg 2018;116:1007.

14. Senturk M, Azgin I, Övet G, Alatas N, Agirgol B, Yilmaz E. The role of the mean platelet volume and neutrophil-to-lymphocyte ratio in peritonsillar abscesses. Braz J Otorhinolaryngol 2016;82:662-7.

15. Onder S, Caypinar B, Sahin-Yilmaz A, Toros SZ, Oysu C. Relation of mean platelet volume with obstructive adenoid hypertrophy in children. Int J Pediatr Otorhinolaryngol 2014;78:1449-51.

16. Walsh SR, Cook EJ, Goulder F, Justin TA, Keeling NJ. Neutrophil-lymphocyte ratio as a prognostic factor in colorectal cancer. J Surg Oncol 2005;91:181-4.

17. Sarraf KM, Belcher E, Raevsky E, Nicholson AG, Goldstraw P, Lim E. Neutrophil/lymphocyte ratio and its association with survival after complete resection in nonsmall cell lung cancer. J Thorac Cardiovasc Surg 2009;137:425-8.

18. Thomas MR, Storey RF. The role of platelets in inflammation. Thromb Haemost 2015;114:449-58.

19. Zahorec R. Ratio of neutrophil to lymphocyte counts rapid and simple parameter of systemic inflammation and stress incritically ill. Bratisl Lek Listy 2001;102:5-14.

20. Acharya AB, Shetty IP, Jain S, Padakannaya I, Acharya S, Shettar L, et al. Neutrophil-to-lymphocyte ratio and platelet-to-lymphocyte ratio in chronic periodontitis before and after nonsurgical therapy. J Indian Soc Periodontol 2019;23:419-23.

21. Sagit M, Korkmaz F, Kavugudurmaz M, Somdas MA. Impact of septoplasty on mean platelet volume levels in patients with marked nasal septal deviation. J Craniofac Surg 2012;23:974-6.

22. Park Y, Schoene N, Harris W. Mean platelet volume as an indicator of platelet activation: Methodological issues. Platelets 2002;13:301-6. 


\section{Adenotonsillektomide Nötrofil-Lenfosit Oranı, Trombosit-Lenfosit Oranı ve Ortalama Trombosit Hacminin Cerrahi Karar ve Takipteki Etkinliği}

Amaç: Adenotonsillektomi ve tonsillektomi en yaygın cerrahi prosedürlerdir. Nötrofil/lenfosit oranı, trombosit/lenfosit oranı ve ortalama trombosit hacmi enflamasyon belirteçleri olarak kullanılabilir. Çalışmanın amacı, adenotonsillektomi ve tonsillektomi hastalarında bu enflamatuvar belirteçlerin değerlerinin takipte etkili olup olmayacağını veya cerrahi karar için gösterge faktör olup olmadığını belirlemektir.

Gereç ve Yöntem: Kronik tonsillit ve tonsil hipertrofisi nedeniyle ameliyat edilen 194 hastanın tıbbi kayıtları ve ameliyat öncesi kan değerleri geriye dönük olarak incelendi. Ameliyat sonrası birinçi ayda tam kan hücresi sayısı (CBC) değerleri değerlendirildi. Kontrol grubu olarak pediatri kliniği tarafından takip edilen normal değerlere sahip 83 hastanın CBC kayıtları alındı.

Bulgular: Çalışma grubundaki 194 hastanın ameliyat öncesi nötrofil/lenfosit oranı değerleri ameliyat sonrası değerlere göre anlamlı olarak yüksekti. Trombosit/lenfosit oranı değerleri önemli ölçüde farklı değildi. Ortalama trombosit hacmi açısından ameliyat öncesi, sonrası ve kontrol grupları 3 grupta istatistiksel olarak birbirinden farklıydı. Parametreler enfeksiyon sayıları açısından incelendiğinde nötrofil/lenfosit oranı, trombosit/lenfosit oranı ve ortalama trombosit hacmi değerleri açısından gruplar arasında anlamlı farklılık gözlenmedi.

Sonuç: Adenotonsillektomi ve tonsillektomi hastalarında tekrarlayan enfeksiyon sayısı, nötrofil/lenfosit oranı, trombosit/lenfosit oranı ve ortalama trombosit hacmi açısından ameliyat öncesi ve sonrası değerler açısından anlamlı farklılık yaratmadı. Ancak cerrahi işlem uygulanan hastalarda nötrofil/lenfosit oranı normal popülasyonda ve ameliyat sonrası dönemde ameliyat öncesi döneme göre anlamlı olarak daha yüksekti. Bu nedenle nötrofil/lenfosit oranı'nın tonsillit hastalarında enflamatuvar bir belirteç olarak kullanılabileceğine inanıyoruz.

Anahtar Sözcükler: Kronik tonsillit; nötrofil-lenfosit oranı; ortalama-trombosit- hacmi; tonsillektomi; trombosit-lenfosit oranı. 